\title{
Front Matter: Volume 11675
}

, "Front Matter: Volume 11675," Proc. SPIE 11675, Synthesis and Photonics of Nanoscale Materials XVIII, 1167501 (26 April 2021); doi:

$10.1117 / 12.2596719$

SPIE. Event: SPIE LASE, 2021, Online Only 


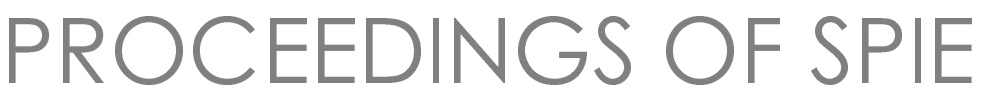

\title{
Synthesis and Photonics of Nanoscale Materials XVIII
}

\author{
David B. Geohegan \\ Andrei V. Kabashin \\ Jan J. Dubowski \\ Maria Farsari \\ Editors
}

6-11 March 2021

Online Only, United States

Sponsored and Published by

SPIE 
The papers in this volume were part of the technical conference cited on the cover and title page. Papers were selected and subject to review by the editors and conference program committee. Some conference presentations may not be available for publication. Additional papers and presentation recordings may be available online in the SPIE Digital Library at SPIEDigitallibrary.org.

The papers reflect the work and thoughts of the authors and are published herein as submitted. The publisher is not responsible for the validity of the information or for any outcomes resulting from reliance thereon.

Please use the following format to cite material from these proceedings:

Author(s), "Title of Paper," in Synthesis and Photonics of Nanoscale Materials XVIII, edited by

David B. Geohegan, Andrei V. Kabashin, Jan J. Dubowski, Maria Farsari, Proc. of SPIE 11675, Sevendigit Article CID Number (DD/MM/YYYY); (DOI URL).

ISSN: 0277-786X

ISSN: 1996-756X (electronic)

ISBN: 9781510641853

ISBN: 9781510641860 (electronic)

Published by

SPIE

P.O. Box 10, Bellingham, Washington 98227-0010 USA

Telephone +1 3606763290 (Pacific Time)

SPIE.org

Copyright @ 2021 Society of Photo-Optical Instrumentation Engineers (SPIE).

Copying of material in this book for internal or personal use, or for the internal or personal use of specific clients, beyond the fair use provisions granted by the U.S. Copyright Law is authorized by SPIE subject to payment of fees. To obtain permission to use and share articles in this volume, visit Copyright Clearance Center at copyright.com. Other copying for republication, resale, advertising or promotion, or any form of systematic or multiple reproduction of any material in this book is prohibited except with permission in writing from the publisher.

Printed in the United States of America by Curran Associates, Inc., under license from SPIE.

Publication of record for individual papers is online in the SPIE Digital Library.

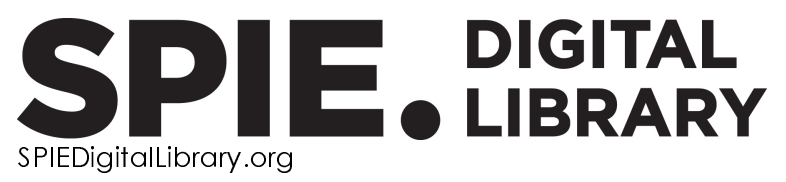

Paper Numbering: A unique citation identifier (CID) number is assigned to each article in the Proceedings of SPIE at the time of publication. Utilization of CIDs allows articles to be fully citable as soon as they are published online, and connects the same identifier to all online and print versions of the publication. SPIE uses a seven-digit CID article numbering system structured as follows:

- The first five digits correspond to the SPIE volume number.

- The last two digits indicate publication order within the volume using a Base 36 numbering system employing both numerals and letters. These two-number sets start with 00, 01, 02, 03, 04, 05, 06, 07, 08, 09, OA, OB ... 0Z, followed by 10-1Z, 20-2Z, etc. The CID Number appears on each page of the manuscript. 


\section{Contents}

SYNTHESIS AND CHARACTERIZATION OF NANOSCALE QUANTUM MATERIALS

1167503 Plasmonic uni-traveling-carrier photodiode [11675-1]

1167504 In situ electron-beam processing and cathodoluminescence microscopy for quantum nanophotonics [11675-2]

1167505 Room-temperature molecular layer deposition of inorganic-organic hybrid aluminum oxide thin films for preventing spin relaxation of cell inner wall of optically pumped atomic magnetometer [11675-3]

$1167506 \quad$ Nanodiamonds by laser filamentation in ethanol [11675-4]

SYNTHESIS AND PROCESSING OF ATOMICALLY-THIN 2D MATERIALS

$116750 \mathrm{C}$ Laser patterning and crystallization of 2D materials on rigid and flexible substrates [11675-10]

11675 OF Laser-based synthesis of atomically thin monolayer 2D quantum materials [1 1675-13]

\section{SIMULATING LASER INTERACTIONS AT THE NANOSCALE}

$11675 \mathrm{OL} \quad$ Effective medium-based optical real-time control over plasmon tuning in laser-induced nanocomposites (Invited Paper) [1 1675-19]

11675 ON Raman spectroscopy of colloidal nanoparticles: are we measuring what we think we are measuring? [11675-22] 
Proc. of SPIE Vol. 11675 1167501-4 Downloaded From: https://www.spiedigitallibrary.org/conference-proceedings-of-spie on 26 Apr 2023
Terms of Use: https://www.spiedigitallibrary.org/terms-of-use 